\title{
A Study of the Deep Differences Between Eastern and Western Philosophies in Ideological and Political Education
}

\author{
Yulian $\mathrm{Xu}^{1{ }^{1 *}}$ Ailin $\mathrm{Xie}^{2}$ \\ ${ }^{1}$ Nanchang University College of Science and Technology, Nanchang, Jiangxi, China \\ ${ }^{2}$ Nanchang Jiaotong Institute, Nanchang, Jiangxi, China \\ *Corresponding author. Email: $495892071 @ q q . c o m$
}

\begin{abstract}
Eastern philosophy and Western philosophy are of great value to education management, and they still have a profound impact on education management, education system, teaching methods, education content, education practice, and education reform and so on. We should study and compare the root, theory and effect of the Eastern philosophy and the Western philosophy, absorb them in reference, merge them in optimization and develop them in sublation. In the ideological and political education, we should pay attention to the combination and fully consider the consistency brought by Chinese and Western philosophy. There are deep-seated differences between Chinese and Western education, but there is no right and wrong. China's education has bred 5000 years of excellent cultural heritage, while Western education has ignited the light of modern science and technology. It's like a piece of white paper with both sides. With different painting styles, you can draw masterpieces of extraordinary craftsmanship. Only when we understand the differences and know ourselves and the other can we make education always new. On the other hand, even though the huge cultural differences between China and the West result in many differences in education, Chinese and Western education still have similarities. That is, no matter what kind of value standards or education methods, the ultimate goal of education is to guide the learners to self-awareness and self-motivation, master the basic knowledge of the system, form the transferable skills such as creative ability and critical thinking, and form the spirit of lifelong learning and pursuing their own excellence.
\end{abstract}

Keywords: Eastern philosophies, Western philosophies, Ideological and political education, Deep differences.

\section{INTRODUCTION}

Fan Wenli (2020) believes that in the vision of building a community of shared future for mankind in the new era, the mission of "Oriental philosophy" research is to achieve dialogue and understanding between oriental cultural traditions and between eastern and Western cultural traditions through

*Fund: Research on the provincial project of teaching reform in Colleges and universities of Jiangxi Province

"Research on the promotion of Ideological and political affinity under the 'positioning method' and 'relationship method' Taking the course 'Introduction' of a university as an example" (subject number: JXJG-20-35-3); project of Jiangxi education science "13th five year plan" in 2020 "Research on the development track and intervention of children's self-supporting behavior in the change of family structure" (20YB357). exchanges and mutual learning among philosophical circles. [1]To achieve this kind of exchange and mutual learning, we need to understand philosophical research from the perspective of transcending geography and crosscultural tradition through comparative philosophy or integrated philosophy, and carry out philosophical dialogue on the scale of human civilization. Wang Xiangyuan (2021) believes that "Oriental philosophy" is the highest level of "Oriental" regional identity. [2] The confirmation of "Oriental philosophy" plays a leading role in the theoretical construction of Orientalism. Despite the fact that education has been an activity since the beginning of the human race and that many places and people are still content with educational 
practices, as George F Naylor points out: "those who do not think in terms of philosophy are necessarily superficial." Without the guidance of philosophy, people's understanding of education will be confined to the narrow and superficial nature of experience, thus the education of the overall self-standard, process, substance and method feel at a loss. In fact, in the history of mankind, any era with a clear theoretical understanding of education is closely related to the development of philosophy in this era.

\section{INDIAN PHILOSOPHY}

We can say that ancient India was the earliest and most developed country in the world, a country of religion, a country of philosophy, a country of poetry; however, people usually equate Indian philosophy with Buddhism, and think that there is nothing but Buddhism in Indian philosophy. In fact, Buddhism can be regarded as the peak of Indian thought, but it is not enough to generalize the whole of Indian thought. Besides Buddhism, there are also a variety of philosophical theories, such as Vedas philosophy, Jingxing calligraphy philosophy, Upanishad philosophy and various schools of philosophy. These theories are very popular among great powers. Among them, the UPANISHADS' profound and mysterious observations on the universe of human life have won the admiration of modern Western philosophers such as Sherrin and Arthur Schopenhauer. Indian philosophy has always made the ideal of the unity of thought and life, and very little of it arises from purely scientific or philosophical interests themselves. Indian thought is full of practice, especially religion, and its religion is based on philosophy, so philosophy and religion are always connected, inseparable, to achieve the ideal life, can not be observed outside the search, you can only use VIPASSANA, or meditation, or Yoga, which is the real way to find the truth. The view of the self or the mind as the FULCRUM and channel for the observation of the universe is the position of the UPANISHADS which permeates all the systems of thought in India, even in Buddhism, which flaunts the doctrine of non-egoism; it can be said that, the ultimate goal of Indian philosophy is the realization of the true self. So in India, theory and practice, religion and philosophy have always been one and the same, without religion, and without philosophy.

\section{CHINESE PHILOSOPHY}

"Philosophy" is a social ideology that studies human thought and cognition of society, everything and the universe. Pay Attention to enlightenment wisdom, cause people's thinking on the sublimation. The West pays attention to the practice, therefore has produced the modern physics, and has been walking in the world front row. China pays attention to the thought, therefore has had the unique Chinese philosophy.

In ancient China, Confucianism, Taoism, legalism and Mohism were the main philosophical schools, especially confucianism, Taoism and Mohism. The introduction and development of Western philosophy in modern times also had a great impact, among which the Marxist philosophy was designated as the official ideology of the Chinese Communist Party in mainland China, and scholars represented by Neo Confucianism, it tries hard to let the Chinese traditional philosophy be able to innovate and develop. In the aspect of Chinese cosmology, the I Ching and Daojia as the representatives of ethical social outlook are the Confucianism and Taoism, which complement each other and are venerated by the rulers and the confucianists of all dynasties.

Confucianism, which originated from the doctrine of Confucius and Mencius, has a long history in the development of Chinese culture. It has a profound influence on the general ethics of the Chinese people and on the values and values of Chinese culture. It has become a collective subconscious of the Chinese nation. Confucian values influenced most public occasions in ancient China with Confucian values as the preferred criterion. Therefore, it can be said that the value orientation of Confucianism in general represents the basic value priority of Chinese traditional culture. Confucianism pays attention to selfcultivation and ethics, the central idea is "benevolence and justice", that is, people should pay attention to the harmonious relationship. [3]

Taoism advocates the way of getting along with nature. If we take heaven as the way and act in accordance with it, we can eliminate disasters. The reason why the difficult problems in human society cannot be solved is because of the excessive intervention, so we should advocate the behavior of doing nothing to achieve the rest. Taoism also yearns for the simple society of returning to simplicity, and thinks that human beings can get rid of the disputes and troubles by not adding any 
artificial function to things and returning to the original simple, ignorant and carefree state.

Han Feizi advocated "learning from Huanglao", linking "reason" and "Tao" together, that "Tao" is to become the law of the operation of all things. The combination of Confucian Benevolence and righteousness and legalist governance resulted in the rule of Huang and Lao in the Early Han Dynasty.

"Zhongxuan" was a very influential ideological trend in the Jin, Sui and Tang dynasties. She is a kind of pure philosophical thinking, not belonging to which school or school, but being integrated and applied by Confucianism, Taoism and Buddhism. "Taoism emphasizes Metaphysics", "Laoxue emphasizes metaphysics" and "Taoism emphasizes metaphysics" have their meanings covered each other, but they can not be regarded as a whole, it should be said that as the different denotation of the "profound way", there are its existence basis. Zhongxuanxue inherited the lao-zhuang school in the pre-qin and Han dynasties and the metaphysics in the Wei and Jin dynasties, and through careful and rigorous theoretical analysis, chinese philosophy established the first complete philosophical system of ontology, ontology, methodology, self-cultivation, mind nature, and meaning, it achieved the third stage development of Daojia's study, which is equivalent to the study of lao-zhuang in the pre-Qin and Han dynasties and metaphysics in the Wei and Jin dynasties. [4]

In the middle of the Ming Dynasty, Wang Yangming inherited Lu Jiuyuan's theory of mind and set up the theory of Yangming, which is the key to conscience.

\section{WESTERN PHILOSOPHY}

The definition of Western Philosophy is equivocal. In the American philosopher Tilly's A History of Western Philosophy, though it mentions Marxism's former socialist philosophers like Owen, but not a word about Marxism. (Tilly's A History of Western Philosophy is about Ancient Greek philosophy to American positivism, including Marxism.). Although Marxism is mentioned in Russell's A History of Western Philosophy, he says he speaks of Marxism because Marxism was a philosopher who had a great influence on Western philosophy. And the Scholasticism phase of Western philosophy often includes a group of Arab philosophers. Therefore, "West" in Western philosophy is widely regarded as not only referring to the "West" in the region, but also referring to the "West" in the culture with "speculative" characteristics.

Although the philosophy of Ancient Greece is based on myths and legends, the Gods and the heroes of demigods in myths and legends are the projections of modern people. Some scholars, referring to the character of the gods in the Ancient Greek mythology, have pointed out that the gods of most nations claim to have created the world, while the gods of Olympus do not claim to have done so. All they did was conquer the world. That's the beauty of the Ancient Greek mythology, which is a mythological reflection of the positive and enterprising attitude of the ancient Greeks.

Ancient Greek and Roman philosophy, which can be broadly divided into three stages:

The 7th to 6th centuries BC, philosophers pay attention to the study of the origin of the universe, this stage of philosophy known as the natural philosophy. As a result of different answers to the original world, philosophers live in different areas, the formation of the Milesian School, the school of love, the Pythagorean School, the Eleatics, and so on. 25th century BC, the Ancient Greek philosophy shifted its focus from nature to humans. The wise man of the time did not believe in real existence and objective truth; the Protagoras believed that everything was equally true, right and wrong, good and evil, relative to human perception; and the Gorgias believed that everything was equally false. Socrates, who called himself the 'sage lover' , argued that there is objective truth and that it is possible to know truth; that true knowledge is to seek universal definitions of morality from specific moral acts; and that the way to seek definitions is to argue and question them. In 4th century BC, the Ancient Greek philosophy entered a systematic phase, represented by Plato and Aristotle. Plato put forward the theory of ideas, that the real, perceptible world is not real, there is an eternal, real world of ideas beyond it. The idea is the 'model' of the individual thing; the individual thing is the imperfect 'shadow' or 'copy' of the perfect thing; the feeling of taking the individual thing as the object cannot be the source of true knowledge, and true knowledge is the 'memory' of the immortal soul of the idea. Aristotle disagrees with Plato's theory of ideas, which he calls 'forms', and argues that 'forms' cannot exist independently of individual things, and that forms are the essence of things and exist within things. 
In the Middle Ages, the Catholic church dominated the secular life and the spiritual life, and the philosophy became the Servant of the theology. The 5th-10th century was the early period of medieval philosophy, during which the focus of philosophical research was on the relationship between the universal and the individual. From the beginning of the 14th century to the middle of the 15 th century, due to the decline of the church and the development of the natural sciences, the Orthodox Scholasticism gradually declined, philosophy became more and more divorced from theology, the thought of individual freedom began to germinate, and medieval philosophy gradually transitioned to modern philosophy.

The early 15 th to 17 th centuries was the first stage of modern Western philosophy. At the center of this period were man and nature, forming the humanism and the natural philosophy, which were interrelated but somewhat distinct. The humanism advocates a people centered, all for the benefit of people, against the immortality of the soul and asceticism. From the beginning of the 17 th century to the end of the 18th century is the second stage of modern Western philosophy. At this stage, the attention of philosophy is focused on the relationship between the cognitive subject and the cognitive object, forming two schools of empiricism and rationalism. In the name of $\mathrm{F}$. Materialism empiricism, represented by Bacon and Roch, holds that acquired feelings about the outside world are sources of knowledge, and feelings are reliable. Take Descartes and G. W. The Idealism theory, represented by Leibnitz, holds that only on the basis of a perfectly clear and unquestionable axiom, and through the capacity of reason to reason clearly and accurately, to get real knowledge. From the philosophy of Immanuel Kant at the end of the 18th century, the Western modern philosophy entered the third stage, which was called 'German classical philosophy' in the history of philosophy, mainly represented by Immanuel Kant, J. G. Johann GOTTLIEB FICHTE, F. W. J. Sherrin, Hegel and Ludwig Feuerbach. Their Unity of opposites made the absolute idea itself evolve along the model of Syllogism, so that it was externalized into the natural world, the evolution of the natural world gave rise to human beings and human society with the ability of self-recognition. The understanding of human beings gradually develops from the understanding of the natural world to the understanding of oneself and consciousness itself, and finally reaches the complete self-knowledge of absolute idea, and the whole world returns to the absolute idea itself.

A philosophical system that has a certain influence in the history of the development of world philosophy, there is also Korean philosophy, Japanese philosophy, Pakistani Philosophy, Sri Lankan philosophy, Vietnamese philosophy, Iranian philosophy, Arab philosophy, Russian philosophy and other regional philosophy. They are more or less influenced by the three philosophical traditions, but they have their own characteristics of philosophical thinking. In the Middle Ages, Arabic philosophy played the role of the medium to spread Aristotle philosophy to Western Europe, and it also developed Aristotle philosophy and became an important link in the history of world philosophy. [5]

\section{EDUCATIONAL PHILOSOPHY}

Philosophy of education, is the discipline of studying the basic problems of education with certain philosophical viewpoints and methods. The ancient thinkers discussed the basic problems of education according to their own philosophical thoughts. The term philosophy of education was first used by the City University of New York at the 1832 to train public school teachers to give lectures on the philosophy of education. In 1848, the German philosopher Karl Rosenkranz (1805-1879) wrote the system of pedagogy, which was translated into English in 1886 by the American educationist Blackett (1836-1911) and named philosophy of education, making it a discipline and a work of art.

From the history of the emergence and development of educational philosophy, it is a relatively young discipline, so from the system to the content, it is still in the stage of different opinions. From the point of view of educational philosophy works at home and abroad, it can be divided into two different systems: (1) Educational Philosophy System which mainly studies the basic problems of education, and (2) Educational Philosophy system which mainly studies the schools of education. The former is exemplified by Dewey's democracy and education, which covers 26 topics ranging from the nature and function of education to textbooks, teaching methods, knowledge, and morality. The latter can be the contemporary American educational philosopher G. F. NIL $\breve{A}$ 's introduction to the philosophy of education represents several major schools of educational philosophy, including pragmatism, 
progressivism, essentialism, eternalism, reformism, existentialism, and Analytic Philosophy. Some educational philosophy works, both the above two systems of content, such as contemporary American Education Philosopher J. S. Brubacher, the philosophy of modern education. Both Eastern and Western philosophies have had a significant impact on education. In China, the ancient thinkers Confucius, Mozi, Mencius, Xunzi, etc., all from their respective philosophical, political, moral, human nature, epistemology and other aspects, discussed the issue of education. In Europe, Ancient Greek Philosophy Socrates, Plato, Aristotle, etc., have also used their philosophical views on education.

\section{THE DEEP DIFFERENCES BETWEEN CHINESE AND WESTERN IDEOLOGICAL AND POLITICAL EDUCATION}

\subsection{The Difference of School Education Is the Essential Difference Between the Two}

Western education is a kind of trial education, which let students try first, accumulate experience and draw conclusions, and get the results of their own research. Western education attaches importance to people-oriented, which is conducive to the cultivation of students' innovative ability. Chinese education is a kind of indoctrinated examination oriented education, which directly tells the students of adult experience, so that they can remember and accept it. Results the students lack of innovative thinking. The difference of teachers' role in the classroom Western education is based on humanistic thought. ${ }^{[6]}$ It cultivates people's practical and analytical ability, encourages the freedom of thought, and is responsible for their own words and deeds. The teacher's role, mainly as a guide, protects the root of human creativity - the freedom and autonomy of thought. In China, the classroom belongs to the teacher. The teacher talks incessantly on the platform. The students listen carefully and take notes. They believe in the answers of the textbook and the teacher. It is a kind of tendentious indoctrination education. The lack of close communication between students and teachers results in students' passive acceptance of knowledge. It is more objective and fair for Western education to evaluate students' performance comprehensively. The score is only a reference value. Chinese education cares too much about students' grades. Grades are the lifeblood of students, parents and schools. High scores are the only choice. College entrance examination is a lifelong test. It's not uncommon for students who only look at their grades but don't ask about their abilities.

\subsection{Differences in Family Education}

Western parents cultivate and exercise their children's sense of independence and ability to live independently from an early age. We should attach importance to children's self-training and their free development, and strive to cultivate children into social people who can adapt to various environments and have independent survival ability. Chinese parents, in addition to life, are most concerned about their children's academic performance. [7] It seems that learning well is omnipotent, but little or no attention is paid to children's independent living ability, social adaptability, mental health, moral sentiment and civic awareness. From birth to adulthood, parents have almost everything for their children, such as cooking, washing clothes, cleaning, saving money for their children to go to university, go abroad, get married, raise children, etc. What foreign parents value is exactly what Chinese parents ignore.

\subsection{The Origin of Independent Development of Education}

Since the Spring and Autumn period, a hundred schools of thought have been singing together, and Confucianism has gradually risen. After "dethroning a hundred schools of thought and respecting Confucianism alone" in the Han Dynasty, it has become the most important school of thought in Chinese traditional culture. The influence of Confucianism on Chinese people is not only deeply imprinted in Chinese life, but also affects Chinese education. Confucianism advocates the spirit of "actively entering the WTO". Therefore, the purpose of children and students receiving education is to integrate into the society and benefit the society with the knowledge they have learned. The so-called "cultivating one's morality, regulating one's family, governing the country and balancing the world" embodies the value orientation of Chinese traditional literati incisively and vividly. Different from traditional Chinese culture, Western education pays more attention to self-liberation, truth exploration and breakthrough. Especially after the baptism of the enlightenment and the Renaissance, the Western 
culture pursues more individuality, and at the same time, it also forms the atmosphere of deeply exploring the laws of the universe. [8] Even today in the $21 \mathrm{st}$ century, with the increasing globalization, the huge differences between Chinese and Western traditional culture still have a significant impact on education.

\subsection{The Embodiment of the Deep Differences in Education}

the differences between Chinese and Western education are not superficial differences in teaching methods, but based on different "cores", which drive education to develop in different directions. Specifically, this difference is reflected in the heart of education, value standards and thinking mode. 1) The essence of education. Since childhood, the teacher told us to be a useful person to the society. In the eyes of the Chinese, this kind of thought seems to be taken for granted. Because both the traditional Confucianism and the trend of thought in the new era are telling us that we should learn for the collective interest and become talents for building a better world.[9]In such a cultural background, the essence of education is to let students establish a sense of collective honor and a value system of striving to become talents for the sake of the collective. In Western countries, education is not a means, because it is an end in itself. The significance of education is to guide learners to learn and think, and to explore the mystery and truth of the world. The reason why modern science was born in Europe has a lot to do with the nature of education. 2) Value standard. Since the purpose of Chinese education is to serve the country and society, it is necessary to carry out sufficient moral teaching in the process of education. Therefore, students also need to understand the value standards conveyed by various moral stories. Up to now, "cultivating virtue through education" has become the orientation of national education, and moral education has become an important part of education, which once again shows the essence of Chinese cultural thoughts and values. Because of the strong sense of collective honor, we are willing to contribute, we have strong cohesion, and our education and learning become more practical. The Western civilization always has a strong "sense of exploration", and their education emphasizes logic and rationality, which is the inexhaustible motive force for them to continuously explore the mysteries of all things in the world. [10] Therefore, the essence of Western education lies in "dialectical inquiry", which gives birth to science and technology and promotes the great leap of human society. 3) Mode of thinking. For the sake of "educational value", Chinese education will pay more attention to "skill education" for students. We will first consider what majors or abilities the society needs, and then set up corresponding courses to cultivate students' corresponding abilities. This kind of education mode has become the mainstream mode in today's universities. [11] In today's dynamic Chinese society, countless new opportunities provide the young generation with a broad stage to show themselves, and everyone has the space to play their own creativity. The Western traditional education lays more emphasis on "liberal education", which is what we call "quality education" today. It focuses on cultivating students' comprehensive development ability of understanding, thinking and creation. Today, some colleges and universities in China begin to set up "liberal arts education", such as Xinya College of Tsinghua University and Liberal Arts College of Sun Yat sen University. However, the education still belongs to the category of elite education and has not reached the level of popularization.

\section{CONCLUSION}

Philosophy is the knowledge of wisdom, thinking about the ultimate problem of human beings, to affect the future fate of human education has a profound significance. Compared with the influence of Western philosophy on education, eastern philosophy lays more emphasis on the following concepts:

First, the aim of education is to realize the harmony between human beings and nature. It emphasizes observing nature and understanding nature through walking and pilgrimage. It believes that the study of nature helps in self-reflection and emphasizes the inner life. It is supreme to acquire wisdom, to achieve enlightenment and to achieve transcendence. All methods have been used to achieve this and to derive from wisdom moral, proper means of livelihood, correct social and political behaviour.

Second, there is more diversity in education methods. Hinduism emphasizes traditional oral instruction and reading of Religious Literature; Yoga can free the mind from the fetters of the body, surmount the material world that can be felt, and achieve inner freedom; Zen Meditation, Heart Seal, Zen can make people achieve insight, meditation. 
Third, the position of teachers is more important. All eastern philosophies emphasize the dignity of the teacher and the crucial role that the student plays in gaining new knowledge and insight into life.

Fourth, the eastern philosophy emphasizes the traditional consciousness, the rule consciousness and the system consciousness.

The Eastern and Western philosophies have profoundly influenced such fundamental issues as the nature of education, the teleology of education, the value of education and the methodology of education, it has also influenced the educational problems of ethics, ethics, aesthetics, mentalism, theory of knowledge, theory of morality, sociology, etc. In a word, although the systems are different, generally speaking, one is to discuss the educational problems from the philosophical system, and the other is to make philosophical analysis from the basic problems of education.

Jean-Jacques Rousseau, Immanuel Kant, Johann Gottlieb Fichte, Johann Friedrich Herbart, Schelmacher, Homburg, Nitze, The Yale Report, Newman, Weiber, Durkheim, Alfred North Whitehead, Dilthey, Tappan, Elliott, Bretchenka, Frankfurt School Jürgen Habermas, Confucius, Oigo, Han Feizi, Vedas, neolution, Upanishad and the schools of philosophy, has had a major impact on education.

The trend of thought in education in the West is a Kawa Nonagare Noyoni process. Germanic peoples's pedagogy and Anglo Educational Science are the two paradigms of Western educational thought. The European New Education Movement, the Progressive Education, the reformist education, has formed the modern education ideological trend. The trend of education of essentialism and the trend of education of eternalism have formed a new trend of traditional education. New behaviorism in education, Analytical Philosophy of Education, existentialism in education, phenomenology in education, structuralism in education, pedagogy in spiritual science, empiricism in education, criticism in education, liberation in education, humanism in education, constructivism in education, holism in education, complexity in education, postmodernism in education, lifelong education, education for all in education, inclusive education, etc. all are influenced by the Eastern and Western educational philosophy.

So, Eastern philosophy and Western philosophy are of great value to education management, and they still have a profound impact on education management, education system, teaching methods, education content, education practice, education reform and so on. We should study, study and compare the root, theory and effect of the Eastern philosophy and the Western philosophy, absorb them in reference, merge them in optimization and develop them in sublation.

Therefore, in the ideological and political education, we should pay attention to the combination and fully consider the consistency brought by Chinese and Western philosophy. There are deep-seated differences between Chinese and Western education, but there is no right and wrong. China's education has bred 5000 years of excellent cultural heritage, while Western education has ignited the light of modern science and technology. It's like a piece of white paper with both sides. With different painting styles, you can draw masterpieces of extraordinary craftsmanship. [12] Only when we understand the differences and know ourselves and the other can we make education always new. On the other hand, even though the huge cultural differences between China and the West result in many differences in education, Chinese and Western education still have similarities. That is, no matter what kind of value standards or education methods, the ultimate goal of education is to guide the learners to self-awareness and self-motivation, master the basic knowledge of the system, form the transferable skills such as creative ability and critical thinking, and form the spirit of lifelong learning and pursuing their own excellence. Sun Litian and others (2021) believe that only under the guidance of Marxist practical concept, fully understand the similarities and differences between the rational spirit of Western philosophy and the moral spirit of traditional Chinese philosophy, can we creatively complete the philosophical system with Chinese characteristics. [13]

\section{AUTHORS' CONTRIBUTIONS}

Yulian $\mathrm{Xu}$ and Ailin Xie jointly selected the theme, put forward the central idea and the main structure of the article. In their writing, they respectively wrote the Chinese and Western philosophy parts of the article, discussed the representative views and main similarities and differences between Eastern philosophy and Western philosophy, analyzed the educational problems of Eastern and Western philosophy, and analyzed the references. They jointly wrote the first draft of the article. After the completion of the 
article, they exchanged the parts, they wrote for rewriting and re-discussion, and finally completed the paper.

\section{REFERENCES}

[1] Fan Wenli. Reflection on the research paradigm of "Oriental philosophy" in the new era [J]. Philosophical trends, 2020, (05).

[2] Wang Xiangyuan. The Centennial exploration of "Oriental philosophy" and the construction of the history of Oriental Philosophy [J]. Open era, 2021, (03).

[3] Xie Ailin, Xu Yulian, Wang Xinxiang. Paradigm transformation and development of Ideological and political education in Colleges and universities since the reform and opening up, education academic monthly, No. 5, 2020.

[4] Xie Ailin, Wang Lihui, Xu Yulian. Research on the educational environment and resilience model of children from divorced families $[\mathrm{J}]$. Education academic monthly, No. 8, 2019.

[5] Wang Lihui, Xie Ailin. Body aesthetics of Huangdi Neijing from the perspective of ecology [J]. Journal of Jiangxi Normal University (PHILOSOPHY AND SOCIAL SCIENCE EDITION), No. 6, 2018.

[6] Xie Ailin. Exploring the basic experience of Chinese moral education in the past 40 years (1978-2018) [J]. 4th International Conference on contemporary education, social sciences and Humanities (iccesh 2019), international conference papers, CPCI-SSH (original ISTP / ISSHP) and Google academic and CNKI retrieval, June 2019.

[7] Xie Ailin, Xu Yulian, Wang Lihui. The new paradigm of moral education in China: the innovation of the times with great morality, public morality and private morality $[\mathrm{J}]$. Annual academic meeting of China Commission of pedagogy and moral education, June 2019.

[8] Wang Jizhen, Ancient red plum, Xie Ailin. A comparative study of pre Qin Confucian concept of justice and benefit and contemporary college students' values $[\mathrm{J}]$. Research on communication power, issue 4 , 2020.
[9] Wang Jizhen, Xie Ailin, etal. Research on the cultivation of pre Qin Confucian concept of justice and benefit on Contemporary College Students' values $[\mathrm{J}]$. Time report, December 2019.

[10] Xu Yulian, Xie Ailin, et al. The aesthetic implication of socialist core values and the growth of college students [J]. Journal of Jiangxi Electric Power Vocational and technical college, October 2019.

[11] Xu Yulian, Xie Ailin, etal. Factors influencing the integration of aesthetic implication of socialist core values into college students' daily life $[\mathrm{J}]$. Changjiang series, December 2019.

[12] Xu Yulian, Xie Ailin, $\mathrm{Hu}$ Xiaogen. The significance of integrating the aesthetic meaning of socialist core values into college students' daily life and ideological and political constraints $[\mathrm{J}]$. China Journal of multimedia and network teaching, Tsinghua University, December 2019.

[13] Sun Litian, Chang Yufei. Practice: the theoretical node of Chinese and Western Marxist Philosophy Association [J]. Social science front, 2021, (05). 